\title{
Utilizing Innovative Instructional Strategies in the Development of Entrepreneurial Skills in Business Education Students in Ogun State, Nigeria
}

\author{
Temitayo Abosede Akinyele Ph.D ${ }^{1}$, Sunday Olanrewaju Oke Ph.D ${ }^{2}$, \\ Fehintola Fatimoh Bintu Bolarinwa ${ }^{3}$ \\ ${ }^{1}$ Federal College of Education, Abeokuta, Nigeria \\ ${ }^{2}$ Olabisi Onabanjo University, Ago-Iwoye, Ogun State, Nigeria \\ ${ }^{3}$ Federal College of Education, Abeokuta, Nigeria
}

\begin{abstract}
This study focused on Utilizing Innovative Instructional Strategies in the Development of Entrepreneurial Skills in Business Education Students in Ogun State, Nigeria. The study was carried out due to the realization of the writers that most graduates of Business Education in Ogun State Higher Institutions despite their knowledge and skills in Entrepreneurship Education do not get self-employed. They will go about looking for employment, getting underemployed and even being frustrated because of lack of employment. Descriptive survey research was adopted for the study.It was guided by two research questions and two hypotheses. The population of the study consisted of 24 lecturers and 289 final year students studying Business Education in six (6) Higher Institutions in Ogun State. Structured questionnaire containing 30 items on a 5 point Linkert Scale was used to obtain information from the respondents.Three hundred and thirteen (313) questionnaires were administered to respondents and three hundred and nine (309) were retrieved and used for the study. The data collected were analysed using mean and standard deviation while t-test parametric test was used to test the hypotheses at 0.05 levels of significance. The findings revealed amongst others that utilization of innovative instructional strategies in the development of Entrepreneurial Skilled in Business Education Students would make more students put the skilled into practice by becoming self-employed and employers of labour. It was also found out that most lecturers don't apply these strategies because of load of work, lack of skills on this strategy, population of students and non-availability of required resources. One major recommendation was that innovative strategies should be used for better understanding and appreciation of entrepreneurial skill to enhance innovative and creativity.
\end{abstract}

Keywords: Innovative, Strategies, Instructional, Entrepreneurial Skills, Business Education.

\section{Introduction}

The word Entrepreneur originates from the French word entreprendre, which means to undertake. Entrepreneurship has traditionally been defined as the process of designing, launching and running a new business, such as start-up company, offering a product, process or service. It involves the identification of an economic gap within a geographical area and creating valuable ideas for profit making as well as satisfying an inspiration. Venkataraman (1997) sees Entrepreneurship as an activity that involves the discovery, evaluation and exploitation of opportunities to introduce new goods and services, ways of organizing markets, processes and raw materials through organizing efforts that previously had not existed. Hill and McGowan (1999) see Entrepreneurship as a process which involves the efforts of an individual (or individuals) in identifying viable business opportunities in an environment, obtaining and managing the resources needed to exploit these opportunities. The entrepreneurship centre of Miami University, Ohio (2003) in Magaji (2010) perceived entrepreneurship as the process of identifying, developing and bringing a vision to life. The vision may be an innovative idea, an opportunity, or simply a better way to do something. The end result of this process is the creation of a new venture, formed under conditions of risk and considerable uncertainty.

\section{Concept of Entrepreneurship Education}

Entrepreneurship Education has to do with teaching skills and imparting knowledge to those who want to be Entrepreneurs (Amit, 2009). Ezener (2011) defined Entrepreneurship Education as the willingness and ability of an individual to seek out investing opportunities, establish and run Enterprise successfully. He associated the concept with activities such as:

- Identification of investment opportunities.

- Decision making as to the opportunities to exploit.

- Promotion and establishment of the business enterprises.

- Aggregation of scarce resources required for production and distribution. 
- Organisation and management of the enterprises.

- $\quad$ Risk bearing.

- Innovation.

Approaches to teaching and learning of Entrepreneurship Education is classified by Lee and Wong (2004) as follows:

- $\quad$ The Old War Stories Approach

- The Case Study Approach

- $\quad$ The Planning Approach and

- The Generic Action Approach

The Old War Stories Approach attempts to motivate aspiring entrepreneurs by relaying series of successful Entrepreneurship stories and revealing how these individuals became successful entrepreneurs. The Case Study Approach uses cases of existing companies to analyse mechanics of the Entrepreneurial process and to elicit students' proposed solutions to the companies' problems. The Planning Approach usually takes the form of a business plan that consists of objectives, budgets and programmes. The Generic Approach emphasizes the formulation of optimal entrepreneurial actions based on existing market forces.

Jack and Anderson (1998) asserted that the teaching of Entrepreneurship is both in a science and out where the former relates to the functional skills required for business start-up and the later to the creative aspect of Entrepreneurship. There appears to be a unanimous agreement among Educators that there is need to be a shift emphasis on the scientific to the artistic and creative teaching of Entrepreneurship Education (Shepherd and Douglas, 1997).

\section{Innovative Instructional Strategies}

Innovative instructional strategies engage students with different kinds of stimuli activity based learning. Education is a light that shows mankind the right direction to surge. The purpose of Education is not just to make students literate but to rationalize issues and situations based on their knowledge and applications of such knowledge to make decisions that benefit them and others.

Modern innovative instructional strategies incorporates technology into teaching-learning methods to recreate rich and more realistic experience for students for a rewarding teaching experience. The writers of this paper looked into experimental learning in an innovative way to enhance.

\section{Statement of the Problem}

Entrepreneurship Education is expected to:

- Prepare participants for career success

- Increase capacity for their future learning

- Realise personal fulfillment and

- $\quad$ Contribute to society (Akinyele, 2015).

It is also expected to create awareness of Entrepreneurship as a career option, enhance understanding of the processing, initiating and managing a new enterprise (Adeboye, 2006).

Obasan (2005) also identified five learning objectives as:

- $\quad$ Developing the right attitudes and motivation for start up

- $\quad$ Acquiring the technical abilities and skills needed to develop businesses

- $\quad$ Fostering networks and contacts for Entrepreneurial ventures

- Achieving the sharp intuition to act at the correct movement and

- Attaining the knowledge base and information for new venture development.

Based on all the above, higher institutions of learning in Ogun State started included Entrepreneurship Education in their Business Education Curriculum since 2004. Despite all their knowledge and skill in Entrepreneurship Education, most graduates from these institutions either go about looking for employment, get underemployed or get frustrated because of lack of employment.

The researchers then got concerned and thought of getting more of the products of these institutions getting self-employed and becoming employers of labour instead of being underemployed, or frustrated because of lack of employment. A pilot study of graduates of these schools carried out by one of the authors between 2007 and 2011 showed that most students who performed poorly in Entrepreneurship Education while in the College, Polytechnic and Universities in Ogun State are not interested in putting the course into practice after graduation. Akinyele (2015) reported that students of Entrepreneurship Education in Business Education Department who had outstanding scores showed interest and make moves to becomes Entrepreneurs after graduation. 
This finding led to the writers looking into how to improve performance in Entrepreneurship Education to enhance better performances and more of them will be interested in getting self-employed. Innovative instructional strategies being proactive approach to integrate certain processes, tools and methods were considered. Researchers then made attempt to find out how much of modern innovative instructional strategies to teach these students for comprehensive and application after graduation.

\section{Purpose of the Study}

The major purpose of the study was to investigate awareness and utilization of innovative instructional strategies in the development of Entrepreneurship skills in Business Education students in Ogun State, Nigeria. The study was carried out to specifically find out:

1. The extent of awareness of innovative strategies that can be used to develop Entrepreneurship by Business Education lecturers.

2. Ascertain the benefits of such innovative strategies in the development of Entrepreneurship skills in Business Education students.

\section{Research Questions}

1. To what extent are Business Education lecturers aware of modern innovative instructional strategies that can be used to develop Entrepreneurship skills in their students?

2. What are the benefits of innovative strategies are used by lecturers to develop Entrepreneurship skills in Business Education students.

\section{Hypotheses}

The following hypotheses were formulated and tested at 0.05 level of significance.

1. There is no significant difference between the awareness of lecturers and that of students regarding available innovative instructional strategies for developing Entrepreneurship skills in Business Education students.

2. There is no significant difference between the opinion of lecturers and the students regarding benefits of utilizing innovative instructional strategies in the development of Entrepreneurship skills in Business Education students.

\section{Method}

Descriptive Survey Research Design was adopted for this study. Lecturers and students of institutions offering Business Education in Ogun State were used as respondents and data collected from them using 30 items or 5 Point Likert Scale was used to obtain data, which was analysed and the results used for conclusion and recommendation. The Area of the study is Ogun State, Nigeria.

\section{Population}

The population of the study consists of 30 percent of all final year Business Education students for 2014/2016 session from six (6) higher institutions running Business Education in Ogun State, Nigeria. Four (4) Lecturers were also selected from each of the Institutions to make twenty-four (24) lecturers. The population is shown in the table below:

\begin{tabular}{|l|l|l|}
\hline S/N & INSTITUTION & NO. OF STUDENTS \\
\hline 1. & Olabisi Onabanjo University, Ago-Iwoye & 140 \\
\hline 2. & Tai Solarin University of Education, Ijebu-Ode & 245 \\
\hline 3. & Federal College of Education, Abeokuta & 250 \\
\hline 4. & Tai Solarin College of Education, Ijebu-Ode & 140 \\
\hline 5. & Federal Polytechnic, Ilaro & 97 \\
\hline 6. & Moshood Abiola Polytechnic, Abeokuta & 91 \\
\hline & Total & $\mathbf{9 6 3}$ \\
\hline
\end{tabular}

Field Survey, 2016.

\section{Sample Technique}

$30 \%$ of the population and 24 lecturers served as respondents for the research work. The researcher adopted systematic random sampling technique to arrive at the sample size. The sample size is shown in the table below.

\begin{tabular}{|l|l|l|l|}
\hline S/N & INSTITUTION & NO. OF STUDENTS & NO. OF LECTURERS \\
\hline 1. & Olabisi Onabanjo University, Ago-Iwoye & 42 & 4 \\
\hline 2. & Tai Solarin University of Education, Ijebu-Ode & 74 & 4 \\
\hline 3. & Federal College of Education, Abeokuta & 75 & 4 \\
\hline 4. & Tai Solarin College of Education, Ijebu-Ode & 42 & 4 \\
\hline
\end{tabular}


Utilizing Innovative Instructional Strategies in the Development of Entrepreneurial Skills in ..

\begin{tabular}{|l|l|l|l|}
\hline 5. & Federal Polytechnic, Ilaro & 29 & 4 \\
\hline 6. & Moshood Abiola Polytechnic, Abeokuta & 27 & 4 \\
\hline & Total & $\mathbf{2 8 9}$ & $\mathbf{2 4}$ \\
\hline
\end{tabular}

\section{Instrument for Data Collection}

Instrument for data collection was a questionnaire with 30 items structured on a 5-point rating scale of Strongly Agreed, Agreed, Undecided, Disagreed and Strongly Disagreed with values of 5, 4, 3, 2 and 1 respectively.The questionnaire was divided into two Sections A \& B to answer questions regarding the awareness of innovative instructional strategies and the assumed benefits of using such strategies. The instrument was validated by lecturers in Business Education in two of the Institutions. The Research Questions were answered using mean and standard deviation. Any mean score of 2.50 and above are accepted while any mean score below 2.50 was rejected.Student t-test statistics was used in testing the hypotheses.

\section{Results}

Research Question 1

1. To what extent are Business Education Lecturers aware of modern innovative instructional strategies that can be used to develop Entrepreneurship skills in their students?

Table 1: Mean rating and Standard Deviation of lecturers and students on awareness of innovative instructiona strategies that can used to develop Entrepreneurship skills in Business Education students

\begin{tabular}{|l|l|l|l|l|}
\hline S/N & ITEMS & X & SD & REMARKS \\
\hline 1. & $\begin{array}{l}\text { Innovative instructional strategies are applied by Lecturers in teaching and } \\
\text { learning Entrepreneurship in Business Education Department }\end{array}$ & 4.05 & .56 & Agreed \\
\hline 2. & $\begin{array}{l}\text { Technology is needed to effectively teach and learn Entrepreneurship } \\
\text { Education }\end{array}$ & 3.83 & .37 & Agreed \\
\hline 3. & $\begin{array}{l}\text { Problem based learning is a good means of teaching Entrepreneurship } \\
\text { Education }\end{array}$ & 3.41 & .49 & $\begin{array}{l}\text { Agreed } \\
\text { Agreed }\end{array}$ \\
\hline 4. & Peer Tutoring is a good means of teaching Entrepreneurship Education & 4.64 & .73 & Agreed \\
\hline 5. & Project Based Learning & 4.61 & .68 & Agreed \\
\hline 6. & Inquiry learning & 4.75 & .52 & Agreed \\
\hline 7. & Scaffolding & 4.84 & .47 & Agreed \\
\hline 8. & Project method & 4.97 & .14 & Agreed \\
\hline 9. & Role play & 3.41 & .49 & Agreed \\
\hline 10. & Excursion/Field Trip and collaborative study & 4.58 & .73 & Agreed \\
\hline 11. & Community mapping & 4.82 & .53 & Agreed \\
\hline 12. & Brainstorming & 4.80 & .47 & Agreed \\
\hline 13. & Smartphones, Modems, Ipad etc. & 4.35 & .42 & Agreed \\
\hline 14. & Skype, Facebook, Twitter and other social media & 4.44 & .88 & Agreed \\
\hline 15. & Smart boards, World Wide Web, Web TV and CDs, Drives etc. & 4.93 & .34 & Agreed \\
& & 4.83 & .37 & Agreed \\
\hline
\end{tabular}

The results above indicated that all the respondents agreed that the 15 items maintained in the questionnaire should be applied in developing Entrepreneurship skills in Business Education students.

Table 2

Research Question: Mean Rating and Standard Deviation on lecturers and students on benefits of innovative strategies that can be used to develop Entrepreneurship skills in Business Education students.

\begin{tabular}{|l|l|l|l|l|}
\hline S/N & ITEMS & X & SD & REMARKS \\
\hline 16. & $\begin{array}{l}\text { Innovative instructional strategies is learner centred where students may set } \\
\text { their own objectives and explore their learning needs. }\end{array}$ & 4.90 & .45 & Agreed \\
\hline 17. & $\begin{array}{l}\text { Innovative instructional strategies enables 24/7 accessibility to all learners no } \\
\text { matter the age, location and status. }\end{array}$ & 4.44 & .88 & Agreed \\
\hline 18. & $\begin{array}{l}\text { Collaborative learning, problem based learning, scaffolding etc. enables } \\
\text { learning from other people or groups. }\end{array}$ & 4.76 & .68 & Agreed \\
\hline 19. & $\begin{array}{l}\text { Innovative instructional strategies makes learners innovative, creative and } \\
\text { adopting their findings for money making. }\end{array}$ & 4.85 & .43 & Agreed \\
\hline 20. & $\begin{array}{l}\text { Innovative instructional strategies enable learners to learn at their own pace } \\
\text { and ability. }\end{array}$ & 3.86 & .86 & Agreed \\
\hline 21. & $\begin{array}{l}\text { Innovative instructional strategy allows the use of diverse methods of teaching } \\
\text { whereby each student uses method that can help him or her learn. }\end{array}$ & 3.83 & .37 & Agreed \\
\hline 22. & $\begin{array}{l}\text { Innovative instructional strategies makes learning less stressful and cheaper } \\
\text { since travelling and looking for textbooks may be avoided. }\end{array}$ & 4.80 & .47 & Agreed \\
\hline 23. & Innovative instructional strategy. & \begin{tabular}{l} 
Agreed \\
Students taught using innovative instructional strategies are well equipped for \\
\hline 24.82
\end{tabular} & .53 & Ase of modern electronics in modern business and offices. \\
\hline
\end{tabular}


Utilizing Innovative Instructional Strategies in the Development of Entrepreneurial Skills in ..

\begin{tabular}{|l|l|l|l|l|}
\hline 25. & $\begin{array}{l}\text { Better and more learning takes place with the use of innovative instructional } \\
\text { strategies. }\end{array}$ & 4.90 & .45 & Agreed \\
\hline 26. & $\begin{array}{l}\text { Limited number of lecturers can achieve much with the use of innovative } \\
\text { instructional strategies in teaching Entrepreneurship Education }\end{array}$ & 5.0 & .00 & Agreed \\
\hline 27. & $\begin{array}{l}\text { Interactive nature of innovative instructional strategy can enhance better } \\
\text { development of Entrepreneurial skills in Business Education students. }\end{array}$ & 4.64 & .68 & Agreed \\
\hline 28. & $\begin{array}{l}\text { Innovative instructional strategies help to develop and improve skills like } \\
\text { problem solving creativity and communication. }\end{array}$ & 4.82 & .53 & Agreed \\
\hline 29. & $\begin{array}{l}\text { Every students needs are met when innovative instructional strategies are used } \\
\text { to teach Business Education students Entrepreneurship Education. }\end{array}$ & 4.98 & .10 & Agreed \\
\hline 30. & $\begin{array}{l}\text { Innovative instructional strategy are ways of achieving effective and efficient } \\
\text { teaching and learning. }\end{array}$ & 4.62 & .48 & Agreed \\
\hline & Ground mean & $\mathbf{4 . 6 0}$ & & \\
\hline
\end{tabular}

The data presented in table 2 revealed that all the respondents agreed that there are benefits in using innovative instructional strategies in the development of Entrepreneurship skills in Business Education students in Ogun State, Nigeria.

\section{Results of the Test of Hypotheses}

Ho: : There is no significant difference between the opinions of lectures and that of the students regarding the awareness of innovative instructional strategies that can be used to develop Entrepreneurship skills in Business Education students.

\begin{tabular}{|c|c|c|c|c|c|c|c|c|c|c|}
\hline Variables & $\mathbf{N}$ & $\mathbf{X}$ & & SD & & DF & $\mathbf{a}$ & t-cal & t-crit & Decision \\
\hline Lecturers & 24 & 3.72 & .27 & 29 & $\frac{1}{0.05}$ & 1.284 & 0.205 & Rejec & & \\
\hline Students & 289 & 4.90 & .45 & & & & & & & \\
\hline
\end{tabular}

Table 3 above showed that the calculated value of $t$ was 1.284.The $t$-critical value was 0.205 which is greater than the fixed $\mathrm{P}$ value of $0.05(\mathrm{P}<0.05)$. Therefore, the null hypothesis which stated that there is no significant difference between the opinion of lecturers and students regarding awareness of innovative instructional strategy for teaching Business Education students skills to develop Entrepreneurship skills was rejected.

$\mathrm{Ho}_{2}$ : There is no significant difference between the opinions of lectures and that of the students regarding the awareness of innovative instructional strategies that can be used to develop Entrepreneurship skills in Business Education students.

Table 4: Student t-test showing the opinion of lecturers and students regarding the benefits of innovation ..

\begin{tabular}{|c|c|c|c|c|c|c|c|c|}
\hline Variables & $\mathbf{N}$ & $\mathbf{X}$ & SD & DF & a & t-cal & t-crit & Decision \\
\hline Lecturers & 24 & 3.86 & .17 & 291 & 0.05 & 1.78 & 0.081 & Rejected \\
\hline Students & 289 & 4.85 & .33 & & & & & \\
\hline
\end{tabular}

Table 4 showed that at 0.05 level of significance, $\mathrm{t}$-calculated of 1.78 was greater than $\mathrm{t}$-critical of 0.081, therefore the null hypotheses which stated that there is significant difference between the opinion of lecturers and students regarding awareness of innovative instructional strategy for teaching Business Education students skills to develop Entrepreneurship skills was rejected.

\section{Discussion of Findings}

The data in Table 1 gave answers to Research Question 1 by agreeing that all the mentioned innovative instructional strategies are well known to lecturers while most students are not aware of many of them. The findings agreed with the views of Leary and Berge, 2006 that paper-based means of learning continues to be more sustained and widely used than innovative instructional strategies. Lecturers are aware of these strategies but they are only full of theoretical knowledge as the environment does not encourage the use of them. The cost of internet connections and maintenance remain high. Also, the adoptions of innovative instructional strategy are dictated by the available bandwidth. Nigeria contributed only $2 \%$ of the internet users worldwide (Zook, 2004).

The data in Table 2 showed that there are many benefits from the use of different innovative instructional materials as reported by most of the lecturers and some of the students. This is in agreement with Akinyele (2011) who reported that for the country to achieve Vision 20-2020 through Business Education, there is need to utilize improved and individualized instructional strategy to teach all Business Education courses especially skill related courses like Entrepreneurship Education, Accounts, Shorthand etc. 
Quality of an Entrepreneur depends on his or her preparation and his or her preparation. The importance and the trends relating to the use of innovative instructional strategies in the development of Entrepreneurship skills in Business Education cannot be overemphasized and there is no way a graduate of this course can be enthusiastic about self-employment if they do not appreciate the skills acquired or acquire adequate skills.

\section{Conclusion}

There is no doubt about the fact that increasing enrolment, modern technology and diversity of students in Business Education Department trying to acquire Entrepreneurship skills demands for learning flexibility. There is need to apply as many innovative strategies as possible to enhance better appreciation, understanding and interest in the practice of Entrepreneurship Education.

\section{Recommendations}

Based on the findings from this research work, the following recommendations are made:

- It is imperative now for Business Education lecturers to be retrained in modern/innovative instructional strategies. Business Education students should also be encouraged to fully abreast themselves with internet based learning.

- $\quad$ There is need to make Colleges, Polytechnics and Universities to be more conducive with enabling environment for internet based learning or innovative strategies.

- $\quad$ Power generation in the country should be worked upon so as to ensure availability of power to carry out innovative strategies.

\section{References}

[1]. Adeboye, J. O. (2006). Business Education and Career Opportunities. Business Education Journal 1 6, Pages 64-72.

[2]. Akinyele, T. A. (2011). Achieving Vision 20-2020 through Business Education. A book chapter in contemporary issues in the Educational System. A book in Honour of Dr. Baderinwa Adeyemo JP. Ibadan: JOVAD Educational Publishers, $202-206$.

[3]. Akinyele, T. A. (2015). Effects of Reciprocal Peer-Tutoring and Problem-Based Learning on Colleges of Education Students' Achievement in Entrepreneurship Education in Ogun State, Nigeria. Ph.D Thesis submitted to Faculty of Education, Olabisi Onabanjo University.

[4]. Amit, A. A. (2009). Entrepreneurship Theory and Practice. Maiduguri: Compaq Publishers Ltd.

[5]. Ezener, R. A. (2011). Evaluation of NBTE New Office Technology and Management Curriculum for Nigerian Polytechnic. An Analysis of Entrepreneurship Development, Nigeria. Published in Business Education Journal (ABEN).

[6]. Hellmann, J. H., Paus, E. \& Jucks, R. (2014). How can innovative teaching be taught? Insights from Higher Education. Psychology Learning and Teaching. 13(1) 43-51. http://dx:doi.org(10.2304)plat.2014 13.1.43.

[7]. Hill, J. and McGowan, P. (1999). A Qualitative Approach to Developing Small- Firm Marketing Planning Competences, Qualitative Market Research in Oguntibeju, J. et al (2014). Leadership, Corporate Governance and Entrepreneurship Development in Nigeria. A Mutual Link Journal of Economics and Sustainable Development. Vol. 5, No. 25.

[8]. Jack, S. L. and Anderson, A. R. (1998). Entrepreneurship Education and Entrepreneurial Development. Association of Business Educators of Nigeria Book of Readings 1(6).

[9]. Leary, J. \& Berge, Z. L. (2006). Trends and Challenges of e-learning in National and International Agricultural Development. International Journal of Education and Development Using ICT. Retrieved from http://Ijedict.dec.uwi. edu/viewarticle. php?id=179\&layout=htm.

[10]. Lee, L. and Wong, P. K. (2004). Entrepreneurship Education. A Compendium of Related Issues. Retrieved Sept. 22, 2012.

[11]. Magaji, Z. B. (2010). Empowering Business Education Graduates through Entreprenuership Education. Journal of Business Educational Research and Development. Vol. 1, No. 1 (March).

[12]. Shepherd, D. A. and Douglas, E. J. (1997). Is Management Education Developing or King an Entrepreneurship Spirit? Proceedings of the 1997 USA SBE Annual National Conference on Entrepreneurship. The Engine of Global Economic Development. San Fransisco, California.

[13]. Venkataramen, S.(1997).The Distinctive Domain of Entrepreneurship Research in Afolabi, A. (2015).The Effect of Entrepreneurship on Economic Growth and Development in Nigeria. International Journal of Development and Economic Sustainability. Vol. 3, No. 2 (May).

[14]. Zook, M. (2004). Internet Users Worldwide - Statistic 2004. Outline URL:http://www.zooknic.com/users/global_2004_09html(last accessed: 2007-01-08) 